\title{
BLACK RATS ERADICATED FROM BIG GREEN ISLAND IN BASS STRAIT, TASMANIA
}

\author{
by Susan Robinson and Wayne Dick
}

(with four text-figures and four tables)

\begin{abstract}
Robinson, S. \& Dick, W. 2020 (9:xii): Black Rats eradicated from Big Green Island in Bass Strait, Tasmania. Papers and Proceedings of the Royal Society of Tasmania 154: 37-45. https://doi.org/10.26749/rstpp.154.37 ISSN: 0080-4703. Biosecurity Tasmania, 13 St Johns Avenue, New Town, Tasmania 7008, Australia (SR*); Tasmania Parks and Wildlife Service, Furneaux Field Centre, 2 Lagoon Road, Whitemark, Tasmania 7255, Australia (WD). *Author for correspondence. Email: sue.robinson@dpipwe.tas.gov.au

Big Green Island is a 129-ha Nature Reserve and part of the Furneaux Group of islands in Bass Strait, southeastern Australia. Beginning in April 2016, Black Rats Rattus rattus were targeted for eradication using poisoning with 50 ppm brodifacoum wax blocks via a $25 \mathrm{x}$ $25 \mathrm{~m}$ grid of bait stations (16 stations per ha) checked daily for a four-week period followed by three one-week visits over an eight-week period. After six weeks, rodent chew-cards were deployed exposing pockets of rat activity on the island. Island-wide monitoring led to the capture of six rats, the last known rat being killed in November 2016. Monitoring for signs of rats proceeded for a further two years and the island was declared rat-free in November 2018. The project encompassed partnerships between government agencies, industry and non-government organisations, and involved a significant volunteer contribution.
\end{abstract}

Key Words: island eradication, invasive species, rodent, Black Rat, Rattus rattus, brodifacoum, bait station.

\section{INTRODUCTION}

In 2006 the Australian Government listed exotic rodents (Black or Ship Rats Rattus rattus; Norway or Brown Rats $R$. norvegicus; Pacific Rats R. exulans; and House Mouse Mus musculus) on islands as a key threatening process under the Environment Protection and Biodiversity Conservation Act 1999 (EPBC Act). A threat abatement plan for invasive rats and mice on islands less than 100,000 ha (Commonwealth of Australia 2009) was subsequently developed. The state of Tasmania has over 600 vegetated islands around its coastline, with at least 39 known to have invasive rodents and probably more with unrecorded populations.

Tasmania's first island eradication for rodents (Black Rats) was on Fisher Island (1 ha) in 1974 (Serventy 1977). The next was Macquarie Island (12,800 ha) for Black Rat and House Mouse (plus European Rabbit Oryctolagus cuniculus) in 2011 (Springer 2016). Fisher Island again had rodents eradicated in 2013 (House Mouse and Black Rat, S. Robinson unpublished data).

The Tasmanian Parks and Wildlife Service (PWS) identified there would be significant environmental and economic gains in eradicating Black Rats from Big Green Island Nature Reserve (129 ha) in the Furneaux Group, Bass Strait. The two islets immediately north of the main island were considered potential habitats for small species of seabirds (e.g., Fairy Tern Sterna nereis, White-faced Storm Petrel Pelagodroma marina and Common Diving Petrel Pelecanoides urinatrix) which were likely to be prevented from successfully breeding by the presence of rats. The economic gains from eradicating rats were that the cost of ongoing control through baiting by the PWS would no longer be required, and the reduction in pasture seed loss to rats would be a gain for the island's lessee.

The Black Rat has a global distribution and is listed among the worst invasive species in the world (Global Invasive
Species Database 2019). They likely arrived in Australia with Dutch ships in the 1600s and fully established with European settlement in the 1780s (Banks \& Hughes 2012). Black Rats are generalist omnivores, a trait shared with many successful vertebrate pests. They will eat almost any food up to their own body weight including vegetation, seeds, invertebrates, small vertebrates and the eggs and young of larger vertebrates (Banks \& Hughes 2012). The direct impacts of Black Rat on wildlife are not well documented, with much of the evidence recorded through the recovery of native species after rats are eradicated from islands, particularly in New Zealand (Towns et al. 2006).

An adult Black Rat weighs up to $225 \mathrm{~g}$ and lives about a year. The species has a gestation period of 21 days and weans its young at around 20 days. A female can have 5-10 young per litter and produce up to six litters per year in ideal conditions (Van Dyck \& Strahan 2008).

\section{SITE DETAILS}

\section{Description}

Situated in Bass Strait, $3 \mathrm{~km}$ west of Flinders Island, the main island of the Big Green Island group is 125 ha, mostly granite and gently rising to $30 \mathrm{~m}$ (fig. 1). The island was intensively managed to provide food for the Aboriginal settlement at Wybalena from the 1830s, including sheep, rabbits, Cape Barren Goose (Cereopsis novaehollandiae), Short-tailed Shearwaters (Ardenna tenuirostris) and their eggs (Backhouse 1843). The vegetation is now mostly nonnative pasture species fringed by a coastal strip of native Tussock Grass (Austrostipa stipoides) (Harris et al. 2001). There is a patch of succulent herbfield in the north and invasive African Boxthorn (Lycium ferocissimum) along the northeastern bay, east coast and scattered across the group 


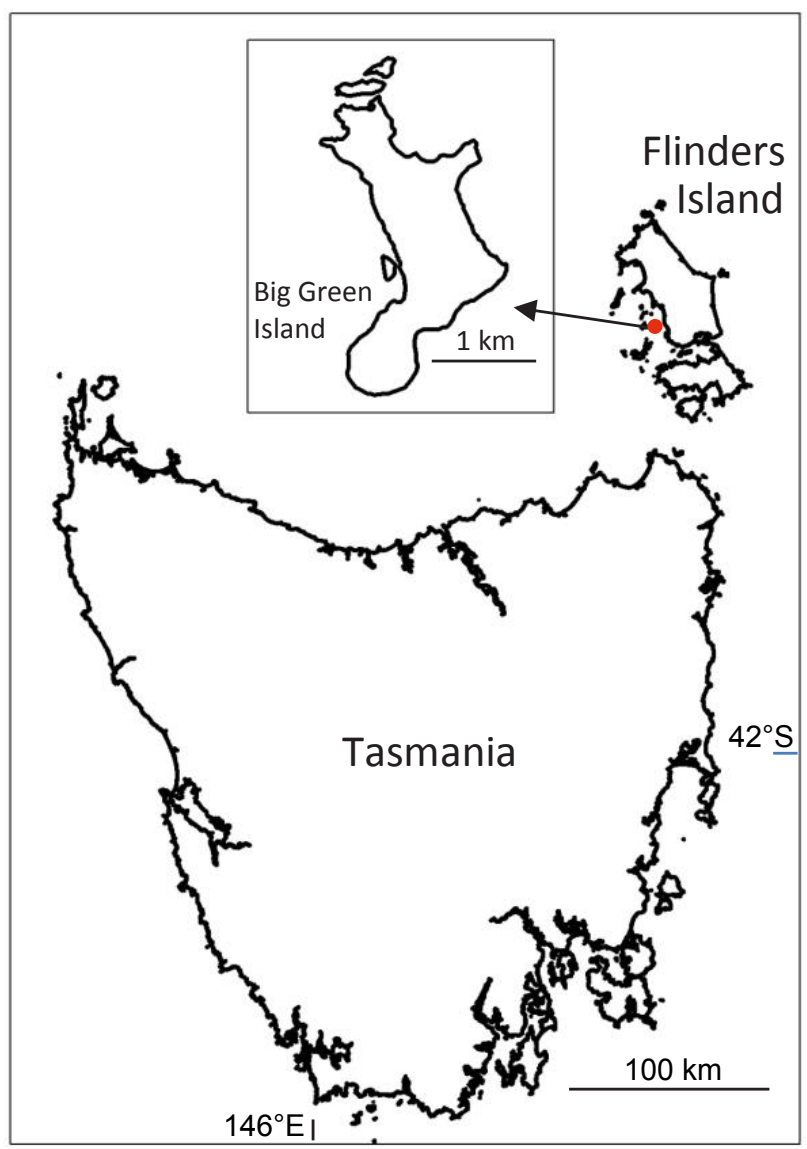

FIG. 1 - Location of Big Green Island relative to Tasmania and Flinders Island.

(Harris et al. 2001). The islets to the north, which are joined by a rocky isthmus at low tides, maintain an assemblage of native plant species including Tussock Grass, Saltbush (Atriplex sp.) and succulents (Sclerostegia sp. shrubs). The main island is fully accessible by foot and the nearby islets require low tides for access.

The freehold island was sold to the PWS in 1980 and declared a Nature Reserve to establish a secure breeding site for Cape Barren Geese which had a declining population at the time. Sheep grazing continued under a lease agreement to maintain the short grass that is favoured by geese. The island has two cottages and a shearing shed that are used by the island's lessee on a regular basis. Access is by boat from Whitemark, Flinders Island, $6 \mathrm{~km}$ to the northeast.

An estimated 22,000 pairs of Short-tailed Shearwater and 400 pairs of Little Penguin (Eudyptula minor) breed on Big Green Island (Brothers et al. 2001). Other breeding seabirds include low numbers of Pacific (Larus pacificus) and Silver Gulls (L. novaehollandiae), Pied (Haemotopus longirostris) and Sooty Oyster-catchers (H. fuliginosus), Black-faced Cormorant (Phalacrocorax fuscescens), Caspian Tern (Sterna caspia) (Brothers et al. 2001) and around 26 breeding pairs of Cape Barren Goose (G. Hocking pers. comm.).

It is unknown when rats arrived, but they likely came with the first settlers to the island in the 1830s. European Rabbit were introduced in 1832 (Backhouse 1843) and died out due to drought around 1914 (D. Cooper pers. comm.). House Mouse were reported around buildings on the island between 1965 and 1968 (Norman 1970) but none have been recorded since then. Flinders Island (3 km away) has Black Rat, Brown Rat and House Mouse.

\section{Rodent baiting history}

Rodent control has been undertaken on Big Green Island sporadically since 1984 by the current lessee. Rats were a significant problem for pasture regeneration due to the consumption of seed-heads. Purchased seed was spoiled through gnawing of packaging and consumed when newly sown. Rodent baiting with sodium monofluroacetate (i.e. 1080) occurred from 1984. From the initial trials with 1080, a regime of frequent poisoning was developed (two to three times a year) using a gridded network of over 700 bait stations (halved plastic 20-litre sheep drench containers). By 1996 the rat population had increased markedly despite continued poisoning. Brodifacoum baits were used until 2003, followed by flocoumafen in 2004 . In 2008, Aegis-RP lockable bait stations were installed to replace the ageing drench containers. An eradication attempt occurred at about this time using one of the secondgeneration rodenticides but was likely unsuccessful due to stations not being regularly refilled beyond the initial bait-take because of difficulties accessing the island and stations not being deployed on the nearby western islet which connected to the main island at low tide.

Development of a rodent eradication plan for Big Green Island by PWS and Biosecurity Tasmania, both divisions within the Department of Primary Industries, Parks, Water and Environment (DPIPWE) commenced in 2013. In 2014 it was decided that all poison bait in the bait stations on the island needed to be removed as soon as practicable to reduce the possibility of rodents becoming physiologically tolerant to toxins due to consumption of sub-lethal doses of degrading bait. Flocoumafen and bromadiolone poison blocks were used until stations were removed in January 2015.

\section{METHODS}

The eradication project was managed by the PWS Flinders Island Field Centre with technical advice provided by Biosecurity Tasmania. A feasibility study was completed in January 2015 (Robinson \& Dick 2015) and recommended ground baiting with stations. An operational plan (Robinson $\&$ Dick 2016) was finalised in February 2016 after being independently reviewed. In January 2015, 864 lockable plastic bait stations were collected, cleared of bait and cleaned. A low number of stations (c. 10) in thick vegetation were not located during this collection. In March 2016, an additional 1,193 new plastic rodent bait stations (Aegis) were taken by barge to the island.

The GPS-linked field data management program Fulcrum (www.fulcrumapp.com) was selected to manage the installation of stations on a $25 \times 25$ m grid (i.e., 16 stations/ 
ha) and bait delivery to this array. Data were recorded in real time and available to the baiting team once uploaded through the mobile phone network. Over 2,200 bait stations were installed by staff and volunteers between 8 and 13 March 2016 using mobile phone network-linked hand-held devices (iPads, Apple) preloaded with Fulcrum and a purpose-built eradication application ('app') with grid points on a Google Earth base-map. The accuracy of iPad GPS is described as 3-6 m, but it was usually within 1-2 $\mathrm{m}$. Additional stations were installed around the buildings, increasing the density to a $12.5 \mathrm{~m}$ grid over 6.25 ha as a contingency for mice. It was decided the buildings would be the most likely place for mice, if still present on the island. A second Fulcrum 'app' was developed in June 2016 for tracking the location and use of monitoring devices across the island.

Islets and outcrops joined to the main island at low tide also had bait stations installed. Additional stations were placed around the coast giving a total of 2,208 bait stations by the end of May 2016. Stations were anchored using a $12 \mathrm{~cm}$ metal spike or a suitable rock. About $100 \mathrm{~g}$ of commercial rodent food pellets (Peckish ${ }^{\mathrm{TM}}$ ) were added to each station and left for five weeks to assist the habituation of rats to entering stations. Twenty rats were trapped for DNA as recommended by Broome et al. (2011) in March 2016. Bird and invertebrate surveys were conducted during April-May 2016 but are not reported on here. Sheep remained on the island for the duration of the program.

\section{Baiting strategy}

The baiting strategy was to use a grid of bait stations across the island with brodifacoum as the active ingredient in wax bait blocks as developed through discussions with the Tasmanian PWS staff, eradication experts in New Zealand, and from the 'Agreed Best Practice for using Bait Stations' (Broome et al. 2011). Stations were to have bait available for four weeks and checked daily, followed by another eight weeks of less frequent checking. It was recommended that baiting could cease one month after the last known bait-take and, if all went well, this would occur within the 12-week baiting period. Because the situation with House Mouse was unresolved, bait station spacing was reduced from the recommended $50 \mathrm{~m}$ (Broome et al. 2011) to a grid of $25 \mathrm{x}$ $25 \mathrm{~m}$. Though this was not a proven spacing for eradicating mice, it would likely provide a greater chance of success with mice if they were present, than $50 \mathrm{~m}$. The alternatives were not considered feasible (i.e., $10 \mathrm{~m}$ grid spacing or aerial baiting). In addition, a 6.25 ha area around the buildings, the most likely place for mice if they were not island-wide, had the bait station grid reduced further to $12.5 \mathrm{~m}$.

Stations were to be installed several weeks in advance of baiting to minimise neophobia in rats around the new bait stations and for baiting to begin in autumn. The breeding season of rats on Big Green Island was unknown but it was considered less likely they would be breeding in autumn and winter. Even if breeding was occurring, the strategy of maintaining baits in stations for 12 weeks should ensure any emerging juvenile rats would be exposed to bait.

\section{Baiting}

Talon X-Pro (Selleys) $20 \mathrm{~g}$ wax blocks containing $50 \mathrm{ppm}$ brodifacoum were secured in stations from 26 April, with the addition of $X$-Verminator (Daviesway) c. $18 \mathrm{~g}$ blocks (50 ppm brodifacoum) from 18 May onwards. Stations had bait checked and replenished daily from 26 April-22 May 2016 (28 days) followed by checks from 6-11 June, 20-26 June, and 4-10 July. Up to six teams of two people checked and replenished all bait stations every 1.5-2 days. A minimum of two baits were provided per station, but some had up to six baits at a time being consumed and these were replaced as needed. Baiting required volunteer teams of at least ten people for three consecutive ten-day shifts (equating to 28 days) followed by three further one-week shifts with at least six volunteers as described above. A total of 56 volunteers and six staff were engaged over the baiting phase of the project. A commercial supplier provided $200 \mathrm{~kg}$ of Talon $X$-Pro and agreed to hold an additional $200 \mathrm{~kg}$ in stock but this was not available when required. X-Verminator was used in its place. A Minor Use permit from the Australian Pesticides and Veterinary Medicines Authority was required for brodifacoum baits to be used for an 'off-label' application (i.e., away from buildings) and covered the use of both Talon $X$-Pro and X-Verminator.

During station checks, data on bait added to stations were entered into the Fulcrum 'app' so that bait consumption could be calculated. Minimal or zero consumption of the second bait X-Verminator occurred due to the rat population being near zero when this bait was deployed. There was also difficulty in distinguishing between possible consumption by rats and crumbling of this bait in some instances, thus no bait uptake estimates for $X$-Verminator are provided in the results.

\section{Monitoring for rat activity}

A range of rodent activity monitoring devices were deployed at various times from week six of baiting, and included chew cards $(35 \times 80 \mathrm{~mm}$ plastic corflute cards containing 5 grams of peanut butter), WaxTags (a waxy peanut butter lure which retains tooth marks; Pest Control Research Ltd. New Zealand) and Reconyx Hyperfire 2 motion sensing cameras distributed in areas of boxthorn and tussock grass, the preferred habitat of rats. Snap traps (Aegis) were set 10-20 $\mathrm{m}$ apart in the areas where monitoring devices indicated rat activity. Other devices used for both monitoring and killing were $\mathrm{A} 24 \mathrm{CO}_{2}$ powered traps (GoodNature) and 'rat motels' (700 x $700 \times 150$ mm, lidded marine ply box internally partitioned containing food, bedding, poison bait, wax tag, snap trap and two $70 \mathrm{~mm}$ entry holes) and baited stations. From late July to early December 2016, eight visits to the island of one week with two staff were undertaken. In 2017, three-day monitoring visits were undertaken every two months then reduced to every three months in 2018 . A rodent detector dog trained for rats and mice visited the island on five occasions, beginning four months after baiting finished (i.e., November 2016). Two years of regular islandwide monitoring concluded the program in November 2018. 


\section{RESULTS}

\section{Stations and bait consumption}

A total of 2,208 stations (tables 1 and 2) had 29,182 visits recorded between 26 April (Day 1) and 10 July 2016, with over $99 \%$ of the bait consumption occurring before 10 May 2016 (Day 15), the period when only Talon X-Pro was used (table $3 \&$ fig. 2). Bait take was highest at Day 5 and decreased to zero (or wasn't discernible) at Day 20 (fig. 2). It was possible a small pulse of bait-take occurred around Day 43 but was difficult to measure due to being very small amounts. Fresh bait remained in stations until at least mid-July (Day 84). A low level of bait uptake recording errors occurred during data entry (typing errors, double entries). Obvious errors were corrected in the database and the remaining error (related to recording bait consumption) was estimated to be $4.4 \%$. An estimated $200.6 \mathrm{~kg} \pm 8.7 \mathrm{~kg}$ (4.4\%) of Talon X-Pro was consumed by rats (table 3 ). The highest bait consumption occurred in coastal areas of African Boxthorn and Tussock Grass, with the mid-east coast of the main island showing pockets of very high consumption (> $640 \mathrm{~g}$, or 32 blocks, per $25 \times 25 \mathrm{~m}$ grid square) (fig. 3). The first dead rat was seen on 28 April and a strong odour of dead rats was discernible by 10 May particularly on the west and north islets.

\section{Locating remaining rats}

Bait-take declined over time and appeared to be at zero by 21 May. Field staff noted, however, that in early June, small amounts of bait may have been consumed and in order to check for possible remaining rats, $381 \mathrm{chew}$-cards were deployed. These were placed $20-50 \mathrm{~m}$ apart and located where bait may have been consumed and in areas of preferred rat habitat including the vegetated perimeter of the island and features such as rocky outcrops between 3 and 8 June. On 10 June, damage to 21 chew-cards indicated rats were still present. In response, the project adopted intensive monitoring with chew-cards, wax tags, snap traps, cage traps, Elliott traps, motion-sensing cameras, tracking tunnels and $\mathrm{CO}_{2}$ powered $\mathrm{A} 24$ traps (table 4). Chew-cards, and to a lesser extent wax tags, were the most effective tools for locating rat activity. Multiple snap traps with a variety of food lures were set in the areas where activity was identified. A total of six rats ( 3 male, 3 female) were killed in snap traps: three in June, two in July and one in November (fig. 4). The last known positive rat sign was an adult female rat killed on 3 November 2016. None of the three female rats were pregnant or lactating. No sign of mice was found.

The grid of baited stations remained in place until midJuly 2016 then was progressively removed over a three-week period beginning with the areas of pasture where bait consumption (a proxy for rat density) had been lowest. Over 30 baited stations were maintained at beaches, landing points and around buildings, in addition to those deployed where rat sign was located. Monitoring equipment remained in place from June 2016 to November 2018 (table 4),

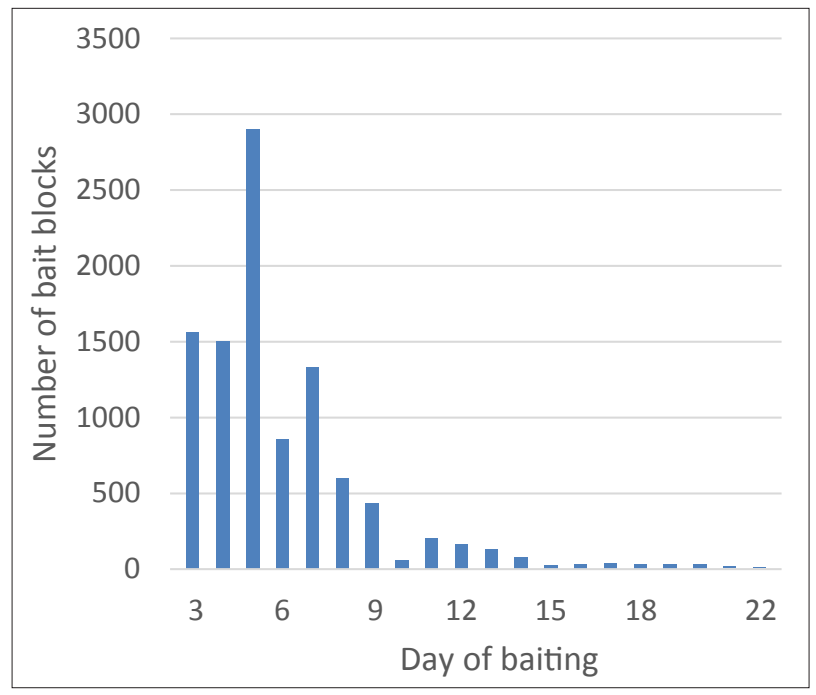

FIG. 2 - Number of $20 \mathrm{~g}$ bait blocks recorded consumed on each day from 28 April 2016 (Day 3) onwards. Initial baiting of stations occurred on Days 1 and 2. Two days were required to check all stations.

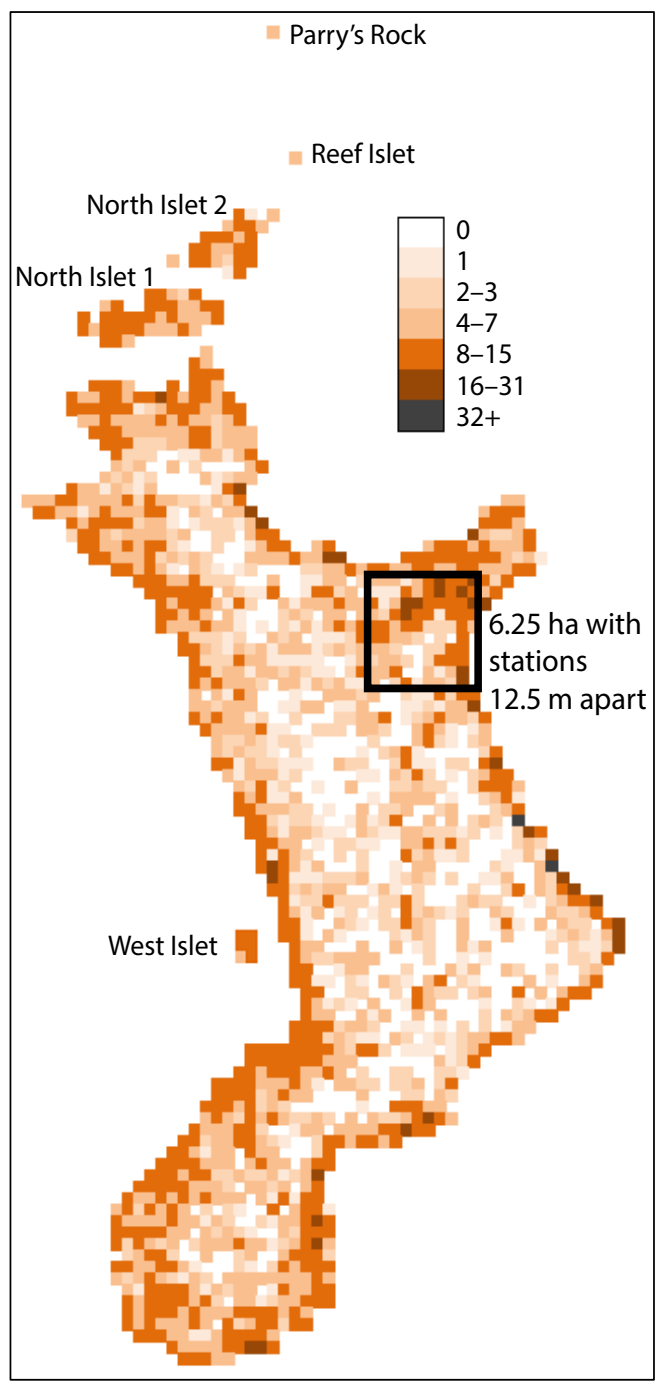

FIG. 3 - Bait block (Talon X-Pro) consumption per $25 \times 25 \mathrm{~m}$ grid square for all the areas of Big Green Island. The highlighted 6.25 ha square contained stations at higher density around the buildings. 
TABLE 1 - Names and areas (above high tide) of individual islands, numbers of bait stations installed and Talon X-Pro bait consumed.

\begin{tabular}{lccc}
\hline Site & Area ha & Number of stations & Bait consumed kg \\
\hline Main island & 124.80 & 2128 & 187.8 \\
West Islet $^{1}$ & 0.18 & 6 & 1.1 \\
North Islet 1 & 2.26 & 40 & 6.9 \\
North Islet 2 & 1.50 & 28 & 4.6 \\
reef islet (no name) & 0.06 & 2 & 0.1 \\
Parry's Rock & 0.11 & 2 & 0.1 \\
TOTAL & 128.91 & 2208 & 200.6 \\
\hline
\end{tabular}

${ }^{1}$ Refer to fig. 3 for locations of islets.

TABLE 2 - Station deployment and visit details.

\begin{tabular}{lcl}
\hline & Total & \multicolumn{1}{c}{ Comment } \\
\hline Total 25 x 25 m grid squares & 2064 & Main island and islets combined \\
Additional stations over 6.25 ha & 93 & Contingency for House Mouse \\
Total stations & 2208 & Includes extra coastal stations \\
Visits to stations (26 Apr-17 May 16) & 18,722 & Talon X-Pro bait only \\
Visits to stations (18 May-10 July 16) & 10,460 & X-Verminator and Talon X-Pro \\
\hline
\end{tabular}

TABLE 3 - Bait deployment and consumption.

\begin{tabular}{lll}
\hline Measure & \multicolumn{1}{c}{ Total } & \multicolumn{1}{c}{ Comment } \\
\hline Total 20 g blocks consumed & 10,028 & Talon X-Pro only \\
Total bait consumed $( \pm$ error $)$ & $200.6( \pm 8.7) \mathrm{kg}$ & Talon X-Pro only \\
Average consumption /station & $0.1 \mathrm{~kg}(5$ blocks $)$ & Averaged over 129 ha \\
Average consumption/ha & $1.6 \mathrm{~kg}$ & Averaged over 129 ha \\
Total bait deployed & $400 \mathrm{~kg}$ & Spoiled baits were removed \\
\hline
\end{tabular}

TABLE 4 - Monitoring tools deployed from 3 June 2016 to the end of the project on 3 November 2018.

\begin{tabular}{|c|c|c|c|c|c|c|c|}
\hline Monitoring tool & 3 Jun-27 Nov $16^{1}$ & 02 Dec 16 & 28 May 17 & 12 Oct 17 & 19 Apr 18 & 22 Aug 18 & 1 Nov 18 \\
\hline Chew-cards & 667 & 383 & 396 & 169 & 187 & 187 & 187 \\
\hline Snap traps & 473 & 3 & 4 & 4 & 3 & 3 & 3 \\
\hline Cage traps & 6 & & & & & & \\
\hline Elliott traps & 5 & & & & & & \\
\hline $\mathrm{CO} 2$ trap locations & 9 & 5 & 5 & & & & \\
\hline Tracking tunnels & 15 & & & & & & \\
\hline Bait stations & c. 40 & 1 & 38 & 37 & 39 & 39 & 39 \\
\hline Wax tags & 89 & 18 & & & & & \\
\hline Camera locations & 16 & & & & & & \\
\hline Rat motels & & & 6 & 6 & 6 & 6 & 6 \\
\hline Rodent detector dog days & 3 & & 3 & 3 & 3 & & 2.5 \\
\hline
\end{tabular}

${ }^{1}$ Total installed over this period 


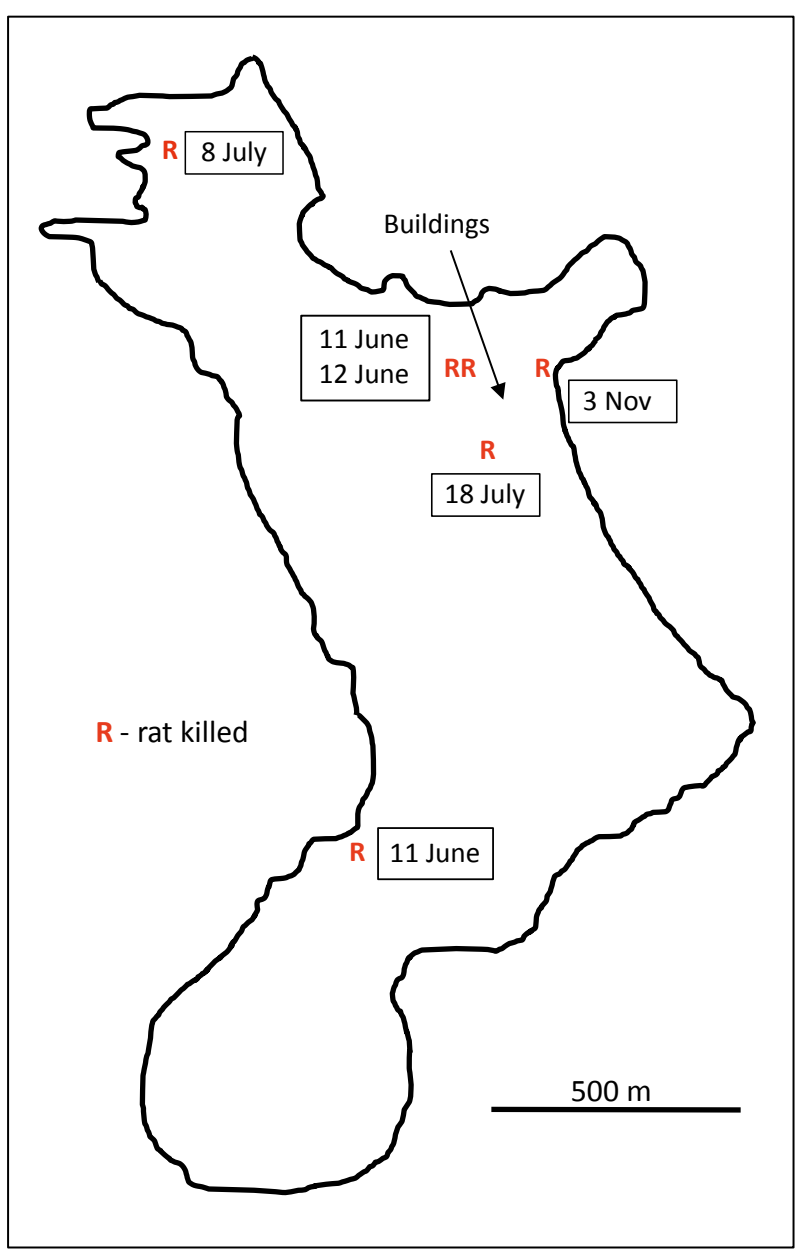

FIG. 4 - Dates and locations of rats killed by snap traps on the main island of the Big Green Island group subsequent to the main baiting knockdown.

which included a two-year monitoring period (Broome et al. 2011) with no further rat sign detected.

\section{Non-target impacts}

Baiting teams were highly vigilant for sick and dead rats with a total of 20 animals collected to reduce the possibility of secondary poisoning of non-target species. Five Pacific Gulls died from consuming poisoned rats as indicated by haemorrhaging seen externally on their carcasses. Trapping resulted in the deaths of three Brown Quail (Coturnix ypsilophora) in uncovered snap traps and a Cape Barren Goose hatchling that squeezed into a station containing a snap trap.

\section{Effort and cost}

Approximately 605 days of volunteer time supported the rat eradication work, with station deployment and baiting consuming the most time. Government agency staff contributed at least 408 days to the project.

Purchases of project equipment and services totalled $\$ 114,000$. Total salary costs were estimated at $\$ 120,000$. In Australia, volunteer time is costed at $\$ 41.72$ per hour (Australian Bureau of Statistics 2018) making the volunteer contribution $\$ 201,925$.

\section{Biosecurity}

A Biosecurity Plan (Tasmania Parks \& Wildlife Service 2016) has been drafted for the island. To minimise biosecurity issues during the eradication program and the monitoring phase, public visitation to the island was suspended until at least November 2016. To reduce the risk of reinvasion of the island by rodents, supplies and equipment travelling to the island are now checked as part of ongoing biosecurity requirements overseen by PWS staff. For on-island biosecurity, six 'rat motels' and 32 baited stations are maintained on the island (including adjacent islets) with checks aimed at 3-6-month intervals.

\section{DISCUSSION}

Tasmania is notable for having achieved the world's largest Black Rat eradication: 12,800 ha Macquarie Island in 2011 (Springer 2016). Interestingly, apart from this and the Big Green Island attempt, the only other island rodent eradications in Tasmania were for the tiny 1 ha Fisher Island in 1974 for Black Rat (Serventy 1977) and again in 2013 for House Mouse and Black Rat (S. Robinson, unpublished data). Big Green Island was one of the 22 'uninhabited' Tasmanian islands recorded with invasive rats and had a long history of rodent control and a previous attempt at eradication. For the eradication attempt described here, potential non-target issues from primary poisoning (i.e., native species and livestock) were minimised by choosing bait stations as the eradication method. The $50 \mathrm{~m}$ grid recommended by Broome et al. (2011) was increased in density to a $25 \mathrm{~m}$ grid as a contingency for the possible presence of mice, accepting that the recommended grid for baiting mice is $10 \times 10 \mathrm{~m}$ (Harper et al. in press). The $25 \mathrm{~m}$ bait station grid required a substantial labour force (mostlyvolunteers) to check stations over the 12-week baiting period and a data management system capable of tracking the distribution of bait over such an array.

The field data management program Fulcrum was integral to the project. Most volunteers quickly mastered the use of iPads and Fulcrum for recording data, though more training would have improved data quality and reduced errors. There were a number of small issues with the data input design related to inexperience of structuring an 'app' for this type of work. The baiting 'app' was not suitable for recording the dynamic situation with monitoring tools being deployed across the island, and a second 'app' specifically for monitoring needed to be produced. In hindsight the monitoring 'app' should have been available at the beginning of fieldwork alongside the baiting 'app'.

Rodent eradication projects on islands generally do not undertake intensive verification monitoring until two rat breeding seasons (equating to two years) after the knockdown (Broome et al. 2011), as for example, Macquarie Island (Springer 2016). This allows time for any rodents to increase in number to a detectable level. The potential issue with this method is that if rodents have survived the eradication attempt, allowing two 
years of reproduction will likely mean the full eradication will need repeating and this additional cost may not be economically viable. The island-wide deployment of monitoring devices after the main knockdown period was not part of the original plan but was suggested by a rodent eradication expert (Department of Conservation, New Zealand) as a good way to check on how the operation was progressing. Other practitioners have used a similar idea and developed detailed rapid eradication assessment models (Samaniego-Herrera et al. 2013, Russell et al. 2017) where monitoring begins soon after baiting and these are particularly suited to smaller islands. A batch of 500 chew-cards was made on the island and these were available for deployment when field staff thought there could be some late bait consumption.

Chew-cards were checked in early June and indicated rat activity. It was possible these remaining rats could have been tolerant to brodifacoum due to the population's long history of exposure to rodenticides or were choosing not to consume bait or to enter bait stations and had thus avoided being poisoned at least at that stage. Bait was still available across the grid and in addition to this, in the case that rats were not entering stations or taking bait, managers decided to allocate staff to actively locate and capture rats, not knowing at the time if there was a high or a low rat population remaining. The appearance of a pulse of activity a few weeks after bait-take has declined to (near) zero is not unusual during a baiting operation (K. Springer pers. comm.). It may have been that remaining rats would have eventually consumed bait if they hadn't been trapped, but the team chose to act to ensure that other lethal methods were available in case the remaining rats were not susceptible to poisoning. Snap traps were firstly set inside stations, which was not successful, then outside of stations under debris and vegetation (to minimise potential bycatch). The main bait station grid was removed between late July and early August 2016 because it was thought remaining rats were avoiding stations, as seen in the lack of success with snap traps set inside stations. Six rats were caught in snap traps between June and November 2016, and no further sign was found during the next two years. The island was declared rat-free in November 2018.

Notwithstanding it is possible all rats could have eventually been killed with poison and that the monitoring could have been delayed, possible explanations for rats being present after the main period of bait consumption include:

Black Rat live for about one year in the wild (Strahan 1983). Ideally an island would be bait-free for at least one year prior to an eradication so that rats exposed to bait during their lifetime (and survived) have died from other causes. The bait-free period prior to eradication for Big Green Island was planned to start in January 2015 when all field-based stations were collected. It transpired in July 2015, however, that sheds and buildings were still being baited which reduced the island's bait-free period to eight months. It was therefore possible that rats that had been exposed to bait, and developed a tolerance to it during this period, could still have been alive at the time of eradication and avoided being poisoned.
The rat population's long history of exposure to multiple poisons may have resulted in the survivorship of neophobic or bait-tolerant individuals over time.

'Bitrex', a bittering agent, was present in the bait Talon $X$-Pro and rats may have been detecting it or repelled by it. Note, however, that $X$-Verminator was also present in stations and does not contain 'Bitrex' so rats may eventually have taken baits if they hadn't been trapped first.

Interestingly, four of the six remaining rats were trapped within $100 \mathrm{~m}$ of the buildings. The risks and implications related to long-term rodenticide use at islands selected for eradication need to be carefully considered during the planning phase. At sites where rodenticides have been used for many years, allowing two years for the site to be free of rodenticide would reduce the chance of bait-tolerant or neophobic individuals being present. This additional time may need to be included in future project planning.

\section{Rat density and bait consumption}

Using bait consumption as an index of rat density showed that native Tussock Grass and African Boxthorn were the most favoured habitats for rats. The highest rat density occurred on the mid-east coast in a narrow strip of African Boxthorn. The nearby islets (West, North Islets 1 and 2) also had high bait consumption (8-15 blocks/grid square) inferring high rat density. The small $(30 \times 20 \mathrm{~m}$ and 45 x $15 \mathrm{~m}$ ), sparsely vegetated, rocky islets to the north also had rats present. These two outcrops join up at low tides. At the lowest tides, a shallow channel $100 \mathrm{~m}$ wide, exists between North Islet 2 and the unnamed 'reef islet', but is well within a rats' swimming ability, with studies concluding Black Rats can swim up to $1 \mathrm{~km}$ distance in favourable conditions (Spennemann \& Rapp 1989), though $500 \mathrm{~m}$ is considered more realistic.

\section{Project partnerships}

The Big Green Island rat eradication project was supported by groups of up to 12 volunteers at a time. Volunteers assisted with a variety of tasks throughout the eradication process: deploying stations across the island; data collection; checking and rebaiting stations; removing stations; constructing, deploying and checking hundreds of chewcards. Significantly, the grid of 2,208 bait stations would not have been an economical option for the project's budget if salaried staff were used. Pre-eradication surveys for birds and invertebrates were conducted by volunteers experienced in these fields.

More and more conservation work is being supported through alternative funding sources and thus projects like these must include strong partnerships between government, industry and non-government organisations. Both the volunteer and philanthropic contributions to this rat eradication project were critical to its success. 


\section{Maintaining a rodent-free island}

Whilst having an island inhabited and with a livestock grazing lease presents challenges for maintaining biosecurity, the presence of the island's leaseholder likely reduces the numbers of opportunistic visitors and campers. Biosecurity guidelines for island visitors are provided on the PWS website. The local PWS staff have biosecurity processes in place to check stock-feed going to Big Green Island and have the responsibility of maintaining the island's rodent bait stations. The time and cost required for biosecurity-related tasks are significantly less than that expended for annual, island-wide and ongoing rodent baiting for control purposes. It is important to note that now the island is free of Black Rats, it is vulnerable to invasion by other species of rodents such as Brown Rats and House Mouse (but also reinvasion by Black Rats) all of which occur on Flinders Island, $3 \mathrm{~km}$ distance at the narrowest crossing. Brown Rats can swim $1 \mathrm{~km}$ (Russell et al. 2008) but have also been recorded swimming at least $2.5 \mathrm{~km}$ (K. Broome pers. comm.).

\section{Post-eradication wildlife monitoring}

Post-eradication monitoring includes the long-term Short-tailed Shearwater monitoring by the Tasmanian Government's Marine Conservation Program. Baseline information on invertebrates, shore birds and other birdlife were collected during the eradication project, and similar surveys will be repeated in the future to examine changes and recovery in native species.

\section{CONCLUSIONS}

Big Green Island has a long history of poison baiting which brought additional considerations into planning for a rat eradication. The project required detailed planning to operate over 2,200 bait stations, a task that was made possible by a mobile phone-linked data collection program and a large group of volunteers. The decision to monitor for rodent activity soon after the main bait consumption period was an important factor in the success of the project because it allowed surviving rats to be located and dispatched before breeding occurred. Effective and ongoing biosecurity for the island is critical for protecting the investment of this rat eradication program, with the island potentially vulnerable to colonisation from any of the three introduced rodent species that occur on nearby Flinders Island. Surveys of shorebirds and small burrowing petrels, as well as invertebrate and reptile fauna, will hopefully soon show the benefits of the work and commitment undertaken to remove Black Rats from Big Green Island.

\section{ACKNOWLEDGEMENTS}

The authors thank all the dedicated volunteers; Tasmania Parks and Wildlife staff Peter Mooney, Cindy Pitchford, Mark Donald, Luke Gadd, Noel Carmichael, Mark Monks, Nick Whiteley and Stan Matuszek; the Tasmania Parks and Wildlife support staff; Biosecurity Tasmania staff and Phil Wyatt for his GIS support. The authors also thank Pete McClelland for expert advice; the Pennicott Foundation; the Estate of G.J. Kole; the island's lessee Dennis Cooper; Peter Vertigan, Greg Hocking and Birdlife Tasmania. Keith Springer and Keith Broome are thanked for their valuable additions to the manuscript.

\section{REFERENCES}

Australian Bureau of Statistics 2018: Assigning value to your volunteer labour, https://www.fundingcentre.com.au/ help/valuing-volunteer-labour

Backhouse, J. 1843: A narrative of a visit to the Australian colonies. Hamilton, Adams and Co., London: 560 pp.

Banks, P.B. \& Hughes, N.K. 2012: A review of the evidence for potential impacts of black rats (Rattus rattus) on wildlife and humans in Australia. Wildlife Research 39: 78-88.

Broome, K.G., Brown, D., Cox, A., Cromarty, P., McClelland, P., Golding, C., Griffiths, R. \& Bell, P. 2011: Current Agreed Best Practice for Rat Eradication - poison bait in bait stations (Version 1.3). New Zealand Department of Conservation internal document DOCDM-839096. Department of Conservation, Wellington, New Zealand: 25 pp.

Brothers, N.B., Pemberton, D., Pryor, H. \& Haley, V. 2001: Tasmania's Offshore Islands: Seabirds and Other Natural Features. Tasmanian Museum and Art Gallery, Hobart, Tasmania: $643 \mathrm{pp}$.

Commonwealth of Australia 2009: Threat Abatement Plan to reduce the impacts of exotic rodents on biodiversity on Australian offshore islands of less than 100000 ha. Unpublished Report of the Department of the Environment, Water, Heritage and the Arts, Canberra: $24 \mathrm{pp}$.

Global Invasive Species Database 2019: 100 of the World's Worst Invasive Alien Species, www.iucngisd.org/gisd/100_ worst.php (accessed 18 August 2019).

Harper, G.A., Pahor, S. \& Birch, D. (in press) The Lord Howe Island rodent eradication: lessons from the groundbaiting operation. 29th Vertebrate Pest Management Conference. University of California (Davis), USA.

Harris, S., Buchannan, A. \& Connolly, A. 2001: One Hundred Islands: The Flora of the Outer Furneaux. Tasmanian Department of Primary Industries, Water and Environment, Hobart: 361 pp.

Norman, F.I. 1970: Food preferences of an insular population of Rattus rattus. Journal of Zoology, London 162: 493-503.

Robinson, S. \& Dick, W. 2015: Big Green Island Black Rat Eradication Feasibility Report. Unpublished Report for Tasmanian Parks and Wildlife Service. Hobart: 22 pp.

Robinson, S. \& Dick, W. 2016: Big Green Island Black Rat Eradication Operational Plan. Unpublished Report for Tasmanian Parks and Wildlife Service. Hobart: 23 pp.

Russell, J.C., Binnie, H.R., Oh, J., Anderson, D.P. \& SamaniegoHerrera, A. 2017: Optimizing confirmation of invasive species eradication with rapid eradication assessment. Journal of Applied Ecology 54: 160-169. 
Russell, J.C., Towns, D.R. \& Clout, M.N. 2008: Review of Rat Invasion Biology. Implications for island biosecurity. Science for Conservation No. 286. Unpublished Report of the Department of Conservation, Wellington, New Zealand: $54 \mathrm{pp}$.

Samaniego-Herrera, A., Anderson, D.P., Parkes, J.P. \& AguirreMunoz, A. 2013: Rapid assessment of rat eradication after aerial baiting. Journal of Applied Ecology 50: 14151421.

Serventy, D.L. 1977: Seabird Islands: Fisher Island, Tasmania. Corella 1(3): 60-62.

Spennemann, D.H.R., Rapp, G. \& Early, D.S. 1989: Can rats colonise oceanic islands unaided? An assessment and review of the swimming capabilities of the genus Rattus (Rodentia: Muridae) with particular reference to tropical waters. Zoologische Abhandlungen des Museums für Tierkunde Dresden, 45(1): 481-491.
Springer, K. 2016: Methodology and challenges of a complex multi-species eradication in the sub-Antarctic and immediate effects of invasive species removal. New Zealand Journal of Ecology 40(2): 273-278.

Strahan, R. (ed) 1983: Complete Book of Australian Mammals. The Australian Museum, Sydney: 530 pp.

Tasmania Parks \& Wildlife Service 2016: Big Green Island Biosecurity Management Plan 2016. Draft Report for Parks and Wildlife Service, Hobart: 21 pp.

Towns, D.R., Atkinson, I.A.E. \& Daugherty, C.H. 2006: Have the harmful effects of introduced rats on islands been exaggerated? Biological Invasions 8: 863-891.

Van Dyck, S.M. \& Strahan, R. (eds.) 2008: The Mammals of Australia. New Holland Publishers, Sydney: 887 pp.

(accepted 30 September 2020) 
